\title{
Preservation of Insulin mRNA Levels and Insulin Secretion in HIT Cells by Avoidance of Chronic Exposure to High Glucose Concentrations
}

\author{
R. Paul Robertson, * Hui-Jian Zhang, " Kathryn L. Pyzdrowski, ${ }^{\star}$ and Timothy F. Walseth* \\ ${ }^{*}$ Diabetes Center and the Division of Endocrinology and Metabolism, Department of Medicine; and ${ }^{\ddagger}$ Department of Pharmacology, \\ University of Minnesota Medical School, Minneapolis, Minnesota 55455
}

\begin{abstract}
Glucose toxicity of the pancreatic beta cell is considered to play a secondary role in the pathogenesis of type II diabetes mellitus. To gain insights into possible mechanisms of action of glucose toxicity, we designed studies to assess whether the loss of insulin secretion associated with serial passages of HIT-T15 cells might be caused by chronic exposure to high glucose levels since these cells are routinely cultured in media containing supramaximal stimulatory concentrations of glucose. We found that late passages of HIT cells serially cultured in media containing $11.1 \mathrm{mM}$ glucose lost insulin responsivity and had greatly diminished levels of insulin content and insulin mRNA. In marked contrast, late passages of HIT cells cultured serially in media containing $0.8 \mathrm{mM}$ glucose retained insulin mRNA, insulin content, and insulin responsivity to glucose in static incubations and during perifusion with glucose. No insulin gene mutation or alteration of levels of GLUT-2 were found in late passages of HIT cells cultured with media containing $11.1 \mathrm{mM}$ glucose. These data uniquely indicate that loss of beta cell function in HIT cells passed serially under high glucose conditions is caused by loss of insulin mRNA, insulin content, and insulin secretion and is preventable by culturing HIT cells under low glucose conditions. This strongly suggests potential genetic mechanisms of action for glucose toxicity of beta cells. (J. Clin. Invest. 1992.90:320-325.) Key words: glucose toxicity • insulin gene $\bullet$ diabetes mellitus
\end{abstract}

\section{Introduction}

The thesis that glucose toxicity plays a secondary role in the pathogenesis of type II diabetes mellitus maintains that after hyperglycemia is established, glucose itself in high concentrations has deleterious effects on pancreatic islet beta cell function (1-18). Type II diabetes is characterized by a specific lack of normal recognition of glucose signals, since all other insulin secretagogues (except glucose) elicit first phase insulin responses when injected intravenously (19-22). Type I diabetes is markedly different in this regard because it is caused by beta cell death and complete absence of insulin secretion. In support of the glucose toxicity concept, defective glucose-induced insu-

Address correspondence to R. Paul Robertson, M.D., The Diabetes Center, Box 101 UMHC, University of Minnesota, Minneapolis, MN 55455.

Received for publication 22 May 1991 and in revised form 13 February 1992.

J. Clin. Invest.

(C) The American Society for Clinical Investigation, Inc.

0021-9738/92/08/0320/06 \$2.00

Volume 90, August 1992, 320-325 lin secretion in type II diabetic patients can be partially reversed by an infusion of exogenous insulin to lower circulating glucose levels into the normal range $(1,5)$. This suggests that hyperglycemia is not only an effect of type II diabetes, but may be a contributing cause of progressive deterioration of insulin secretion. However, as yet no biochemical mechanism for glucose toxicity has been identified (15).

The HIT-T 15 cell is a clonal cell line of pancreatic islet beta cells derived from SV-40 transfection of Syrian hamster pancreatic islets (23). The HIT cell is a valuable research tool because it is one of only a few cell lines that secrete insulin in response to glucose and because it responds to physiologic inhibitors of insulin secretion (23-31). However, insulin content and insulin secretion by this cell line progressively diminish with serial passage $(23,26,30)$. The explanation for this loss of secretion has not been forthcoming, although further transformation of the cell is often mentioned as a possibility by investigators who study this cell line. However, because loss of insulin secretion is highly predictable by passage number and not sporadic in nature, further cellular transformation as a sole explanation seems questionable.

HIT cells are routinely serially cultured by most investigators using media containing concentrations of $11.1 \mathrm{mM}$ glucose (23-31), a concentration that is supramaximal for stimulating insulin secretion from these cells (30). Consequently, we designed studies to address $(a)$ whether the loss of insulin secretion associated with serial passages of HIT cells might be caused by adverse effects of chronic culturing the cells under high glucose conditions; and, if so, (b) whether this phenomenon is associated with an insulin gene mutation, a deficiency in the pancreatic islet glucose transporter (GLUT-2), or decreased levels of insulin mRNA; and, if so, $(c)$ whether such changes might be prevented by culturing the cells in media containing a lower glucose concentration that is more physiologic for HIT cells.

\section{Methods}

Cell culture. Stock cultures of HIT-T15 cells were routinely grown in $5 \% \mathrm{CO}_{2} / 95 \%$ humidified air at $37^{\circ} \mathrm{C}$, maintained in RPMI 1640 medium supplemented with $10 \%$ fetal calf serum, passaged once weekly following detachment using trypsin-EDTA, and fed every $48 \mathrm{~h}$ by changing medium as previously described (30). The final concentration of insulin (from fetal calf serum) in the working media averaged $5-10 \mu \mathrm{U} / \mathrm{ml}$. No antibiotics were used. Beginning with passage 70 , cells were split weekly and continuously passed in media containing either $0.8 \mathrm{mM}$ glucose, a slightly stimulatory concentration, or $11.1 \mathrm{mM}$ glucose, a supramaximal stimulatory concentration (30). Cell population doubling levels and doubling times were determined by plating cells into 12 -well plates $\left(4 \mathrm{~cm}^{2} /\right.$ well) at 0.1 million or 0.5 million cells/well. These conditions reflect the densities at which the cells were routinely cultured. Daily thereafter for $6 \mathrm{~d}$, cells were detached with trypsin- 
EDTA and counted. Viable cells were determined by trypan blue exclusion, and both viable and nonviable cells were counted. The cumulative doubling levels and doubling times were calculated using the following equations:

Number of doubling on day $i=n_{i}=\frac{\log \left[\mathrm{TC}_{\mathrm{i}} / \mathrm{AC}_{(\mathrm{i}-1)}\right]}{\log 2}$

where

$\mathrm{TC}_{\mathrm{i}}=$ total number cells on day $i$ (alive and dead).

$\mathrm{AC}_{(\mathrm{i}-1)}=$ number of alive cells on the day previous to day $i$.

Cumulative doubling level $=\sum^{6} n_{i}$

doubling time $(\mathrm{h})=\frac{24 \mathrm{~h} / \mathrm{d} \times 6 \mathrm{~d}}{\text { cumulative doubling level }}$

Insulin secretion. Static insulin secretion in response to progressively increasing concentrations of glucose $(0-11.1 \mathrm{mM})$ was examined as previously described (30). Phasic insulin secretion in response to $11.1 \mathrm{mM}$ glucose perifusion in the presence of $0.1 \mathrm{mM}$ 3-isobutyl 1-methylxanthine (IBMX) ${ }^{1}$ was examined as previously described (32).

Insulin $m R N A$. Cells were rinsed twice with ice-cold Dulbecco's PBS and scraped on ice with denaturing solution (4 M guanidine thiocynate; $25 \mathrm{mM}$ sodium citrate, $\mathrm{pH} 7 ; 0.5 \%$ sarcosyl; $0.1 \mathrm{M}$ 2-mercaptoethanol). The lysed cells were passed several times through a 22gauge needle to shear chromosomal DNA. RNA was isolated by the procedure of Chomczynski et al. (33). Total RNA (5-15 $\mu \mathrm{g}$ ) was fractionated on $1.5 \%$ agarose-formaldehyde gels and transferred to a nylon hybridization membrane, $(0.22 \mu \mathrm{m}$ micron; Micron Seps. Inc., Westboro, MA) by electroblotting. The membrane was prehybridized in $50 \%$ formamide; $5 \times$ standard saline citrate (SSC); $10 \times$ Denhardt's; 50 $\mathrm{mM}$ sodium phosphate, $\mathrm{pH} 6.5 ; 1 \mathrm{mg} / \mathrm{ml}$ salmon sperm DNA, and $0.1 \%$ SDS at $30^{\circ} \mathrm{C}$ overnight. The membrane was then hybridized overnight with ${ }^{32} \mathrm{P}$-labeled human insulin genomic DNA probe in $50 \%$ formamide; $5 \times \mathrm{SSC}$; $2 \times$ Denhardt's; $50 \mathrm{mM}$ sodium phosphate, $\mathrm{pH}$ $6.5 ; 0.1 \mathrm{mg} / \mathrm{ml} \mathrm{salmon}$ sperm DNA; $0.1 \mathrm{mg} / \mathrm{ml}$ yeast tRNA; and $0.1 \%$ SDS at $30^{\circ} \mathrm{C}$. The membrane was washed twice for $45 \mathrm{~min}$ at $50^{\circ} \mathrm{C}$ in $0.2 \times$ SSC and $0.1 \%$ SDS, and exposed to $x$-ray film (Kodak X-Omat AR) for 16-24 h. The probe was human insulin genomic DNA (phins 214; Amer. Type Culture Collection, Rockville, MD) oligolabeled with $\left.{ }^{32} \mathrm{P}\right] \mathrm{dCTP}(34)$. The probe hybridized with a $0.5-\mathrm{kb}$ band on agarose gel fractionation of total HIT cell RNA consistent with HIT cell insulin mRNA (35). Under the hybridization conditions employed, the probe also labeled HIT cell $18 \mathrm{~S}$ and 28S rRNA, and the density of labeled $18 \mathrm{~S}$ rRNA was proportional to total RNA over the range of total HIT cell RNA applied to gels. Insulin mRNA levels were quantitated by scanning densitometry of autoradiographs; advantage was taken of $18 \mathrm{~S}$ rRNA labeling by normalizing insulin mRNA blots for the density of the corresponding $18 \mathrm{~S}$ rRNA. Therefore, data are expressed as the ratio of density of insulin mRNA to density of $18 \mathrm{~S}$ rRNA. The validity of this approach has been verified by de Leeuw (36). Also, we periodically used a probe for $\beta$-actin mRNA to verify use of $18 \mathrm{~S}$ rRNA for normalization.

Restriction enzyme analysis of insulin gene DNA. DNA was isolated from HIT cells by Maniatis' procedure (37). Genomic DNA was divided into four samples, which were each digested with one of four restriction endonucleases (EcoRI, PstI, HindIII, or BamHI). The restriction fragments were separated by electrophoresis in a $0.8 \%$ agarose gel. BstEII digested lambda phage DNA was used as a size marker. The separated DNA fragments were transferred from the agarose gel to a nylon membrane as described by Southern (38). DNA was retained on the nylon membrane by ultraviolet crosslinking and then hybridized

1. Abbreviation used in this paper: IBMX, 3-isobutyl 1-methylxanthine. with ${ }^{32} \mathrm{P}$-labeled human insulin genomic DNA probe as described above. The restriction fragments containing sequences complementary to the insulin DNA probe were detected by exposing $\mathrm{x}$-ray film to the nylon membrane.

Glucose transporter. The amount of glucose transporter (GLUT-2) was assessed by immunoblot. Antisera (W-19) against GLUT-2 was a generous gift from Dr. Mike Mueckler of Washington University, St. Louis, MO. HIT cell extracts obtained from various passages cultured under various conditions were prepared as described previously and were electrophoresed in $11 \%$ polyacrylamide gels (39). After electrotransfer to Immobilon-P, the immunoblot procedure of Harris et al. (40) was employed using W-19 antisera at a dilution of 1/250.

Statistics. Intergroup comparisons for densitometric data and insulin secretion data were performed by Student's $t$ tests. Data are presented as mean $\pm \mathrm{SE}$.

\section{Results}

Insulin secreted by HIT cells during cell growth. After splitting passage 71 into flasks with media containing either $0.8 \mathrm{mM}$ glucose or $11.1 \mathrm{mM}$ glucose, cells were serially passed for $40 \mathrm{wk}$ by weekly splitting and continued culturing in media containing the initial glucose concentration of either 0.8 or $11.1 \mathrm{mM}$. To compensate for the empirical observation of lesser numbers of cells attached to the walls of flasks when $0.8 \mathrm{mM}$ glucose was used in media, approximately four to five times as many cells were initially plated at the beginning of each week for earlier passages serially cultured in media containing $0.8 \mathrm{mM}$ glucose. In this manner, approximately equal numbers of cells were present by the end of each week when comparing low and high glucose conditions. However, it was ascertained by daily total cell counts in duplicate wells performed in duplicate (the sum of attached cells plus cells floating in media) for seven consecutive days for passages 75,85 , and 95 that the population doubling times and cumulative doubling levels were not significantly different (Fig. 1). Rather, a greater proportion of cells reproducibly detached into the media when they were cultured under conditions of low glucose, which accounted for the lesser numbers of cells attached to the walls of the flasks at the time of subculturing. Initially and through passage 79, HIT cells exposed to the higher glucose concentration secreted insulin into the media that reached levels of $\sim 3,500-4,500 \mu \mathrm{U} /$ million cells per $48 \mathrm{~h}$ (Fig. 2). Thereafter, insulin levels in the media diminished progressively through passage 90 to $\sim 100-250$ $\mu \mathrm{U} /$ million cells. Media insulin levels secreted by cells cultured in $0.8 \mathrm{mM}$ glucose were initially $1,000-2,500 \mu \mathrm{U} /$ million up to
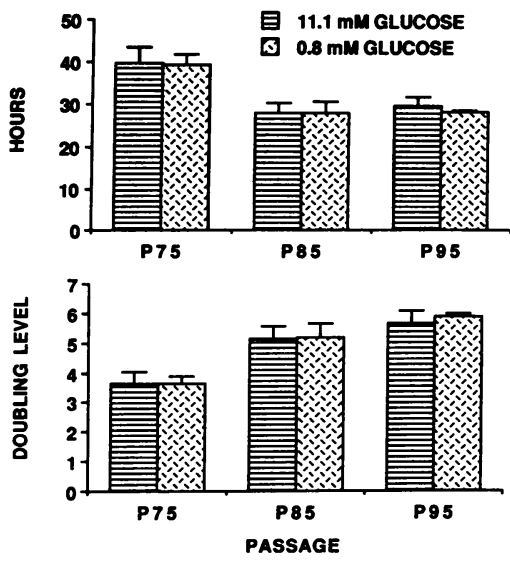

Figure 1. Comparison of HIT cell population doubling times and cumulative doubling levels over $6 \mathrm{~d}$ at passages 75 , 85 , and 95 , when serially cultured in media containing either 11.1 $\mathrm{mM}$ or $0.8 \mathrm{mM}$ glucose 


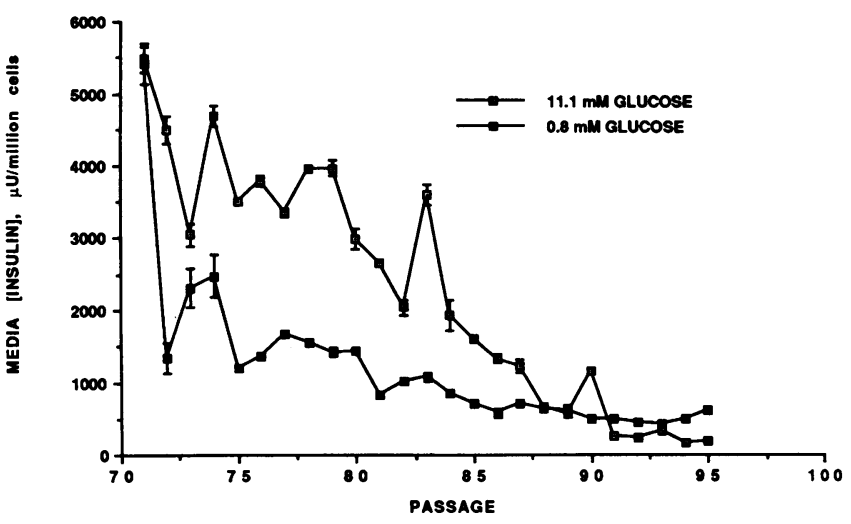

Figure 2. Media insulin concentrations determined after $48 \mathrm{~h}$ of culture in RPMI-1640 containing either low glucose $(0.8 \mathrm{mM})$ or high glucose $(11.1 \mathrm{mM})$ concentrations in serial passages of HIT cells. Data are $\overline{\mathbf{x}} \pm \mathrm{SE}$ for triplicate determinations.

passage 79 , and then declined gradually over time, remaining stable at $\sim 400-1,000 \mu \mathrm{U} /$ million cells from passage 81 to passage 95 .

Insulin secretion during static incubation and during perifusion. Glucose concentration-insulin response curves were determined using selected passages serially cultured in media containing either 0.8 or $11.1 \mathrm{mM}$ glucose. Cells cultured in 0.8 $\mathrm{mM}$ glucose were subcultured in $0.8 \mathrm{mM}$ glucose for $2 \mathrm{~d}$ or in $11.1 \mathrm{mM}$ glucose for 2 or for $9 \mathrm{~d}$ before secretion experiments were performed to stimulate insulin gene transcription and insulin synthesis (35). HIT cells from passages 96-97 serially passed in media containing $11.1 \mathrm{mM}$ glucose failed to secrete insulin in response to glucose during 1 -h static incubations. In striking contrast, late passages of HIT cells serially passed in media containing $0.8 \mathrm{mM}$ glucose demonstrated two- to threefold insulin responses to glucose (Fig. 3), a magnitude usually found in passage 70 cultured in media containing $11.1 \mathrm{mM}$ glucose (30).

Phasic insulin secretion in response to glucose was examined during perifusion with $11.1 \mathrm{mM}$ glucose and $0.1 \mathrm{mM}$ IBMX. Passages 95-98 of HIT cells serially passed in media containing $11.1 \mathrm{mM}$ glucose had no phasic insulin responses to glucose. However, the same late passages of HIT cells that had been serially passed in media containing $0.8 \mathrm{mM}$ glucose and then subcultured in $11.1 \mathrm{mM}$ glucose demonstrated first and second phase insulin responsivity during glucose perifusion (Fig. 4) that was similar in magnitude to that observed in early passages cultured in media containing $11.1 \mathrm{mM}$ glucose (32). Comparable insulin responsiveness was observed when either 2 or $9 \mathrm{~d}$ were used for subculturing in $11.1 \mathrm{mM}$ glucose after cells had been serially passed under low glucose conditions.

Insulin content and insulin $m R N A$. HIT cell passages 70 , $80,90,100,110$, and 130 cultured in media containing 11.1 $\mathrm{mM}$ glucose showed a progressive diminution of insulin content (insulin content $=2468,1730,629,522,379$, and $68 \mu \mathrm{U} /$ mg protein, respectively). Insulin content was greater in passages 87,95 , and 96 when HIT cells were serially cultured in media containing $0.8 \mathrm{mM}$ rather than $11.1 \mathrm{mM}$ glucose (Fig. 5). Correspondingly, insulin mRNA in later passages of HIT cells cultured in media containing $11.1 \mathrm{mM}$ glucose was markedly diminished (Fig. 6), whereas insulin mRNA of HIT cells serially cultured in media containing $0.8 \mathrm{mM}$ glucose was greater compared to cells cultured in media containing 11.1

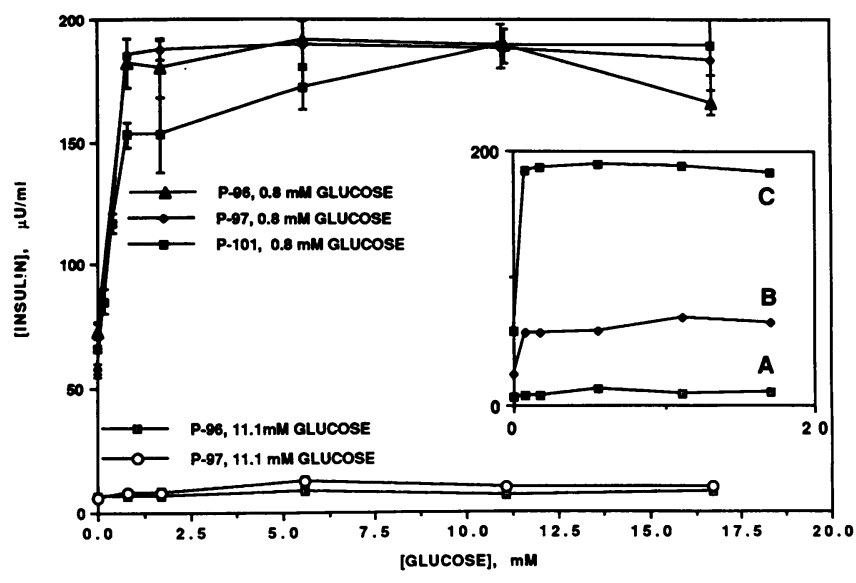

Figure 3. Insulin responses to increasing glucose concentrations in $1 \mathrm{~h}$ static incubations of late passages of HIT cells serially passed in media containing either $0.8 \mathrm{mM}$ glucose or $11.1 \mathrm{mM}$ glucose. Before these studies, cells serially passed in media containing $0.8 \mathrm{mM}$ glucose were cultured in media containing $11.1 \mathrm{mM}$ glucose for 2 or $9 \mathrm{~d}$. Data are $\overline{\mathrm{x}} \pm \mathrm{SE}$ for duplicate experiments for each passage using each condition. Inset compares basal and glucose-stimulated insulin levels in P-97 cells cultured in $11.1 \mathrm{mM}$ glucose $(A)$, in $0.8 \mathrm{mM}$ glucose $(B)$, and in $0.8 \mathrm{mM}$ glucose plus $9 \mathrm{~d}$ subculture in $11.1 \mathrm{mM}$ glucose $(C)$. Both $(B)$ and $(C)$ conditions were associated with approximately twoto threefold insulin release by glucose during the static stimulations, whereas $(A)$ was not.

$\mathrm{mM}$ glucose (Figs. 5 and 7). The experiments in which insulin content and mRNA were observed did not involve subculturing under high glucose conditions but rather were carried out entirely under $0.8 \mathrm{mM}$ glucose conditions.

Southern analysis of insulin gene and Western analysis of GLUT-2. Examination of HIT cells from early and late passages cultured in media containing either $11.1 \mathrm{mM}$ or $0.8 \mathrm{mM}$

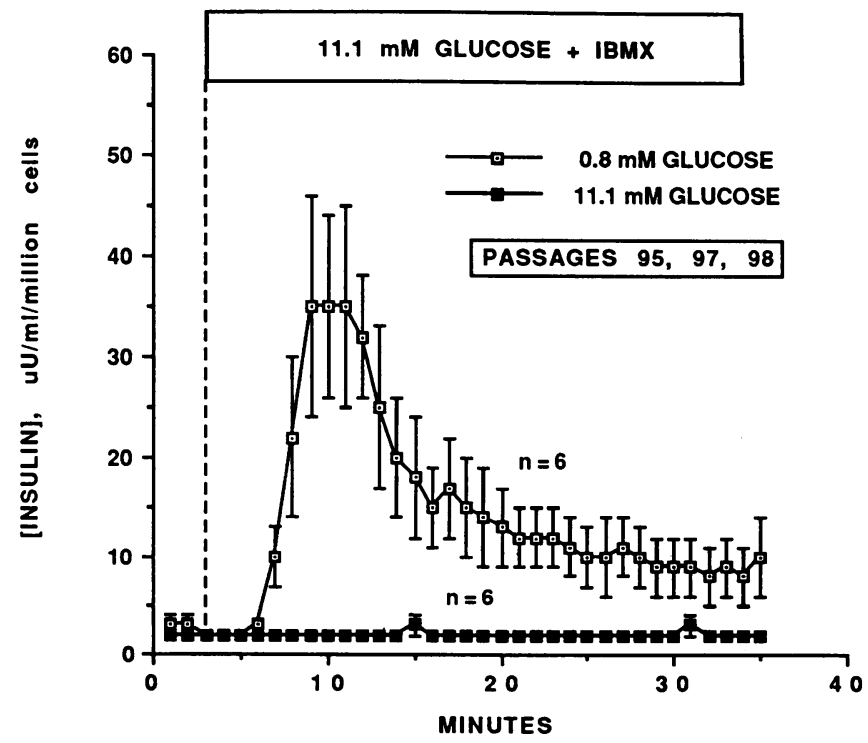

Figure 4. Phasic insulin secretion during perifusion with glucose and IBMX from late passages of HIT cells serially passed in media containing either $0.8 \mathrm{mM}$ glucose or $11.1 \mathrm{mM}$ glucose. Before these studies, cells serially passed in media containing $0.8 \mathrm{mM}$ glucose were cultured in media containing $11.1 \mathrm{mM}$ glucose for 2 or $9 \mathrm{~d}$. Data are $\overline{\mathrm{x}} \pm \mathrm{SE}$ for duplicate experiments for each passage using each condition. 


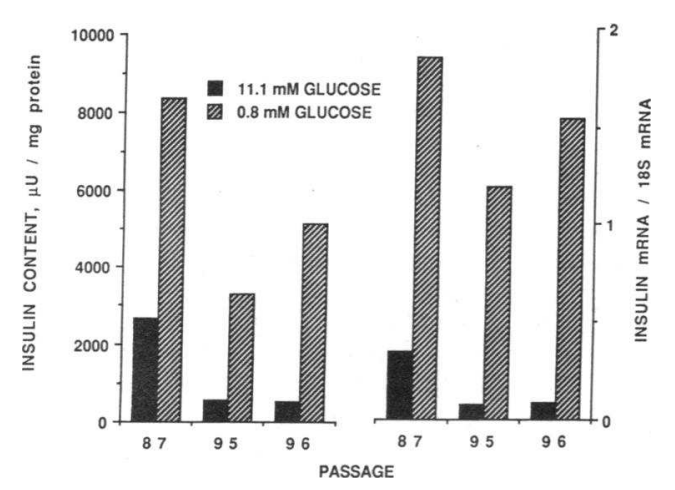

Figure 5. Comparison of insulin content and insulin mRNA levels of HIT cells serially passed in RPMI media containing either $11.1 \mathrm{mM}$ glucose or $0.8 \mathrm{mM}$ glucose. mRNA densitometric data are expressed an insulin mRNA/18S rRNA ratio. Data are means of triplicate experiments for insulin content and duplicate experiments for insulin mRNA using each condition.

glucose failed to reveal differences in insulin gene fragments (Fig. 8) or levels of GLUT-2 (Fig. 9).

\section{Discussion}

The HIT cell has proven to be a valuable experimental model of beta cell function. Insulin secretion from HIT cells is glucose concentration-related and insulin release during perifusion is biphasic (23-31). However, disappointing loss of insulin secretion from HIT cells with serial passage has been a major shortcoming $(23,26,30)$. We considered the possibility that an 11.1 $\mathrm{mM}$ concentration of glucose, which has been routinely used in media for culturing these cells (23-31) and is supramaximal for HIT cell insulin secretion (30), might be responsible for this effect. We found that late passages of HIT cells cultured in media containing $0.8 \mathrm{mM}$ glucose demonstrated normal insulin responsivity to glucose in static incubations and normal first and second phase glucose-induced insulin secretion during perifusion. In contrast, late passages cultured with $11.1 \mathrm{mM}$ glucose had no insulin responses to glucose stimulation as has been previously reported $(23,26,30,32)$. HIT cells as late as passage 96 cultured in media containing $0.8 \mathrm{mM}$ glucose had levels of insulin and insulin mRNA that were greater than those found in late passages of cells cultured in $11.1 \mathrm{mM}$ glucose. Because culturing under conditions of low glucose concentration caused greater numbers of cells to detach from the walls of the culture flasks, it was necessary to seed greater num-

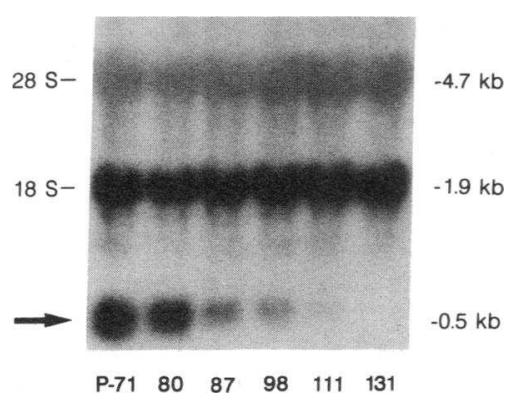

Figure 6. Decreasing levels of insulin mRNA with increasing passage of HIT cells serially passed in media containing $11.1 \mathrm{mM}$ glucose. Arrow designates hybridization of oligolabeled human insulin genomic DNA probe to HIT cell insulin mRNA. Hybridization of probe to $18 \mathrm{~S}$ rRNA was proportional to total RNA.

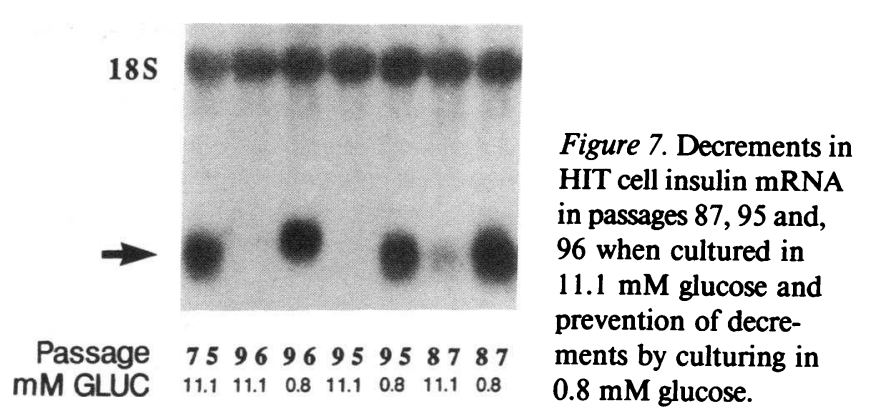

bers of cells in earlier passages in order to harvest comparable numbers of attached cells by the end of each passage. Nonetheless, cell population doubling times and doubling levels were similar at a given glucose concentration at passages 75,85 , and 95 , although with increasing passage doubling times decreased comparably for both glucose concentrations. No insulin gene mutation or decreased levels of GLUT-2, the functional glucose transporter of pancreatic beta cells, were found in late passages of HIT cells conventionally cultured with media containing $11.1 \mathrm{mM}$ glucose. Thus, our data uniquely indicate that loss of beta cell function in HIT cells passed serially in media containing a high glucose concentration is caused by preventable effects of chronically culturing under conditions of high glucose concentrations that are associated with loss of insulin mRNA and insulin content and, consequently, loss of insulin secretion.

Loss of insulin responses to glucose in HIT cells serially passed in media containing high glucose concentrations is reminiscent of abnormal insulin secretion in type II diabetic patients and in rodents that have been made permanently hyperglycemic by a brief exposure to exogenously induced high circulating glucose levels. Patients with type II diabetes mellitus lose first phase insulin responses to glucose if their fasting glucose levels are greater than $115 \mathrm{mg} / \mathrm{dl}$ (41). However, this secretory defect is glucose-specific, since first phase insulin responses to

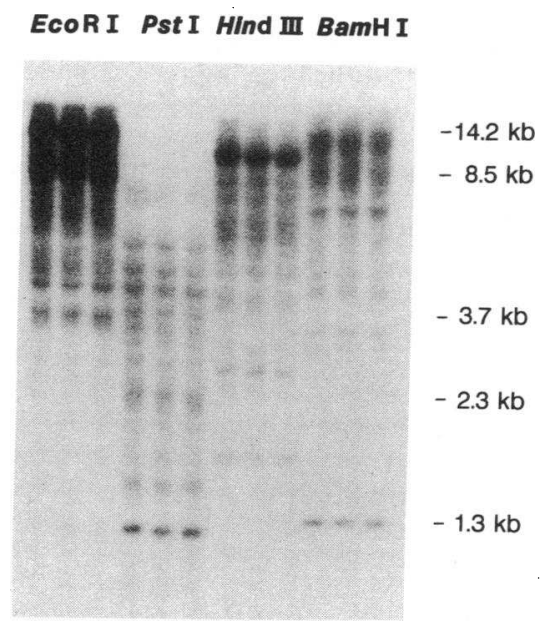

Figure 8. Restriction enzyme analysis for insulin gene mutations in early and late passages of HIT cells cultured in RPMI media containing 0.8 or $11.1 \mathrm{mM}$ glucose. The four restriction endonucleases used are shown above each set of three lanes. No differences in patterns were observed. 
Figure 9. Analysis of GLUT-2 levels by immunoblot in early and late passages of HIT cells cultured in RPMI media containing 0.8 or $11.1 \mathrm{mM}$ glucose; $100 \mathrm{mcg}$ total protein was used in each lane.

non-glucose agonists such as isoproterenol (7), secretin (8), arginine (9), and glucagon (10) remain intact in hyperglycemic diabetic patients even though they are somewhat diminished. An interesting parallelism exists between these observations and our previously published report that HIT cells serially passed in media containing high glucose concentrations lose insulin responses to glucose before they lose insulin responses to arginine (30). It is important to note that lowering of circulating glucose levels into the normal range has been shown to partially restore first phase insulin responses to glucose in diabetic patients (1-5). Likewise, brief intravenous infusions with agents such as phentolamine (42), sodium salicylate (43), and naloxone (44) have also been shown to partially restore first phase insulin responses to glucose despite continued hyperglycemia. The ability of these drugs to restore responses in the face of continued hyperglycemia suggests the possibility that endogenous $\alpha$-adrenergic tone, prostaglandins, or endorphins may mediate some of the adverse effects of chronic hyperglycemia on beta cell function.

The role of established hyperglycemia in the development of sustained abnormalities in insulin secretion has also been examined in animal models. For example, Rossetti et al. induced hyperglycemia and defective insulin secretion in rats by $90 \%$ pancreatectomy and reported that normalization of glycemia by phlorizin treatment of the pancreatectomized animals restored normal insulin secretion (10). Leahy et al. reported that rats undergoing $60 \%$ pancreatectomy developed persistent hyperglycemia and abnormal insulin secretion only if they were temporarily fed high concentrations of sucrose (12). Imamura et al. made similar observations in $80 \%$ pancreatectomized dogs (11). However, although studies in animals have made the point that artificially induced hyperglycemia can cause defective beta cell function, such studies are intrinsically limited by the short duration over which they can be conducted. Since type II diabetes mellitus in humans evolves over a much longer period of time than several weeks, a laboratory model that can be studied over many months or years has clear advantages in examining the dimension of time and precisely chosen glucose concentrations as major variables to assess the concept of glucose toxicity on the islet. We therefore propose the HIT cell as a valuable laboratory model for examining glucose toxicity of beta cells because putative biochemical mechanisms responsible for this phenomenon and maneuvers designed to subvert its mechanisms can easily be examined over many months and potentially years using this cell line. In this context, our finding of undetectable levels of insulin mRNA in late HIT cell passages that can be prevented by culturing cells serially in a low glucose concentration points specifically toward potential genetic mechanisms of action for glucose toxicity on beta cells, which in turn leads to defective insulin secretion. One potential proposal would involve an inhibitory effect

of glucose on insulin gene transcription. This would represent a paradoxical effect because under normal conditions, glucose is a physiologic stimulator of insulin gene transcription $(35,45)$. Should it be found that prolonged exposure to excessively high glucose levels can cause progressively diminished rates of insulin gene transcription, this would provide a possible mechanism for the decreased insulin mRNA levels and loss of insulin secretion we have observed in HIT cells. Alternatively, deleterious effects on insulin mRNA stability and degradation rates need to be considered, and although our restriction fragment analysis studies revealed no abnormalities in the insulin gene in late passages serially cultured in high glucose concentrations, this analytical approach to possible gene mutations can not be considered definitive. Nonetheless, our finding of preventable decrements in insulin mRNA associated with culturing under high glucose conditions points to preexocytotic events for the search for mechanisms of deleterious effects of chronic hyperglycemia on beta cell function in type II diabetic patients. Such effects may contribute to phenomena that are commonly referred to as glucose toxicity, glucose desensitization, or beta cell exhaustion.

\section{Acknowledgments}

The excellent technical assistance of Elizabeth Oseid, Laurie Pohlman, and Beryl Greenberg, and the superb secretarial skills of Paula Rossin are gratefully acknowledged.

This work was supported by grant R01-DK 38325 from the National Institutes of Health.

\section{References}

1. Turner, R. C., S. T. McCarthy, R. R. Holman, and E. Harris. 1976. Betacell function improved by supplementing basal insulin secretion in mild diabetes. Br. Med. J. 1:1252-1254.

2. Schmeltz, R., H. J. Wendorff, and J. B. Field. 1978. Effect of control of blood glucose on plasma insulin responses to various stimuli in secondary failures to oral hypoglycemic agents and in newly diagnosed, maturity onset, ketosis-resistant diabetics. J. Clin. Endocrinol. Metab. 46:519-527.

3. Kosaka, K., T. Kuzuya, Y. Akanuma, and R. Hagura. 1980. Increase in insulin response after treatment of overt maturity-onset diabetes is independent of the mode of treatment. Diabetologia. 18:23-28.

4. Hidaka, H., M. Nagulesparan, I. Klimes, R. Clark, H. Sasaki, S. L. Aronoff, B. Vasquez, A. H. Rubenstein, and R. H. Unger. 1982. Improvement of insulin secretion but not insulin resistance after short term control of plasma glucose in obese Type II diabetics. J. Clin. Endocrinol. Metab. 54:217-222.

5. Vague, P., and J.-P. Moulin. 1982. The defective glucose sensitivity of the B cell in non insulin dependent diabetes. Improvement after twenty hours of normoglycaemia. Metab. Clin. Exp. 31:139-142.

6. Bonner-Weir, S., D. F. Trent, and G. C. Weir. 1983. Partial pancreatectomy in the rat and subsequent defect in glucose-induced insulin release. J. Clin. Invest. 71:1544-1553.

7. Unger, R. H., and S. Grundy. 1985. Hyperglycaemia as an inducer as well as a consequence of impaired islet cell function and insulin resistance: implications for the management of diabetes. Diabetologia. 28:119-121.

8. Giugliano, D., P. Di Pinto, A. Ceriello, G. Paolisso, F. Saccomanno, R. Torella, and F. D'Onofrio. 1985. Glycemic control with an artificial pancreas improves insulin responses to both oral and I.V. glucose in nonobese noninsulindependent diabetic subjects. Acta Diabetol. Lat. 22:203-213.

9. Glaser, B., G. Leibovich, R. Nesher, S. Hartling, C. Binder, and E. Cerasi. 1988. Improved beta-cell function after intensive insulin treatment in severe non-insulin-dependent diabetes. Endocrinologica. 118:365-373.

10. Rossetti, L., G. I. Shulman, W. Zawalich, and R. A. DeFronzo. 1987. Effect of chronic hyperglycemia on in vivo insulin secretion in partially pancreatectomized rats. J. Clin. Invest. 80:1037-1044.

11. Imamura, T., M. Koffler, J. H. Helderman, D. Prince, R. Thirlby, L. Inman, and R. H. Unger. 1988. Severe diabetes induced in subtotally depancreatized dogs by sustained hyperglycemia. Diabetes. 37:600-609.

12. Leahy, J. L., S. Bonner-Weir, and G. C. Weir. 1988. Minimal chronic hyperglycemia is a critical determinant of impaired insulin secretion after an incomplete pancreatectomy. J. Clin. Invest. 81:1407-1414. 
13. Giroix, M.-H., P. Serradas, and B. Portha. 1989. The desensitization of normal B-cells to glucose in vitro is transient and not related to high glucose levels. Endocrinology. 125:1999-2007.

14. Grodsky, G. M. 1989. A new phase of insulin secretion. How will it contribute to our understanding of $\beta$-cell function? Diabetes. 38:673-678.

15. Robertson, R. P. 1989. Type II diabetes, glucose "non-sense," and islet desensitization. Diabetes. 38:1501-1505.

16. Rossetti, L., A. Giaccari, and R. A. DeFronzo. 1990. Glucose toxicity Diabetes Care. 13:610-630.

17. Korsgren, O., L. Jansson, S. Sandler, and A. Andersson. 1990. Hyperglycemia-induced B cell toxicity. The fate of pancreatic islets transplanted into diabetic mice is dependent on their genetic background. J. Clin. Invest. 86:2161-2168.

18. Sako, Y., and V. E. Grill. 1990. Coupling of $\beta$-cell desensitization by hyperglycemia to excessive stimulation and circulating insulin in glucose-infused rats. Diabetes. 39:1580-1583.

19. Robertson, R. P., and D. Porte. 1973. The glucose receptor: a defective mechanism in diabetes mellitus distinct from the beta adrenergic receptor. $J$. Clin. Invest. 52:870-876.

20. Lerner, R. L. 1979. Augmented insulin responses to glucose after secretin priming in diabetic subjects. J. Clin. Endocrinol. Metab. 48:462-466.

21. Palmer, J. P., J. W. Benson, R. M. Walter, and J. W. Ensinck. 1976. Arginine-stimulated acute phase of insulin and glucagon secretion in diabetic subjects. J. Clin. Invest. 58:565-570.

22. Crockford, P. M., W. R. Hazzard, and R. H. Williams. 1969. Insulin response to glucagon: the opposing effects of diabetes and obesity. Diabetes. 18:216-224.

23. Santerre, R. F., R. A. Cook, R. M. D. Crisel, J. D. Sharp, R. J. Schmidt, D. C. Williams, and C. P. Wilson. 1981. Insulin synthesis in a clonal cell line of simian virus 40-transformed hamster pancreatic beta cells. Proc. Natl. Acad. Sci. USA. 78:4339-4343.

24. Swope, S. L., and A. Schonbrunn. 1984. Bombesin stimulates insulin secretion by a pancreatic islet cell line. Proc. Natl. Acad. Sci. USA. 81:1822-1826.

25. Hill, R. S., and A. E. Boyd III. 1985. Perifusion of a clonal cell line of simian virus 40-transformed beta cell. Insulin secretory dynamics in response to glucose, 3-isobutyl-1-methylxanthine, and potassium. Diabetes. 34:115-120.

26. Ashcroft, S. J. H., P. Hammonds, and D. E. Harrison. 1986. Insulin secretory responses of a clonal cell line of simian virus 40-transformed B cells. Diabetologia. 29:727-733.

27. Lambert, D. G., K. Hughes, and T. W. Atkins. 1986. Insulin release from a cloned hamster B-cell line (HIT-T15). The effects of glucose, amino acids, sulphonylureas and colchicine. Biochem. Biophys. Res. Commun. 140:616-625.

28. Meglasson, M. D., C. D. Manning, H. Najafi, and F. M. Matschinsky. 1987. Fuel-stimulated insulin secretion by clonal hamster $\beta$-cell line HIT T-15. Diabetes. 36:477-484.

29. Robertson, R. P., P. Tsai, S. A. Little, H.-J. Zhang, and T. F. Walseth. 1987. Receptor-mediated adenylate cyclase-coupled mechanism for $\mathrm{PGE}_{2}$ inhibition of insulin secretion in HIT cells. Diabetes. 36:1047-1053.

30. Zhang, H.-J., T. F. Walseth, and R. P. Robertson. 1989. Insulin secretion and cAMP metabolism in HIT cells. Reciprocal and serial passage-dependent relationships. Diabetes. 38:44-48.

31. Ullrich, S., M. Prentki, and C. B. Wollheim. 1990. Somatostatin inhibition of $\mathrm{Ca}^{2+}$-induced insulin secretion in permeabilized HIT-T15 cells. Biochem. J. 270:273-276

32. Seaquist, E. R., T. F. Walseth, D. M. Nelson, and R. P. Robertson. 1989. Pertussis toxin-sensitive $G$ protein mediation of $P E_{2}$ inhibition of cAMP metabolism and phasic glucose-induced insulin secretion in HIT cells. Diabetes. 38:1439-1445

33. Chomczynski, P., and N. Sacchi. 1987. Single-step method of RNA isolation by acid guanidinium thiocyanate-phenol-chloroform extraction. Anal. Biochem. 162:156-159.

34. Feinberg, A. P., and B. Vogelstein. 1984. A technique for radiolabeling DNA restriction endonuclease fragments to high specific activity. Anal. Biochem. 137:266-267.

35. Hammonds, P., P. N. Schofield, and S. J. H. Ashcroft. 1987. Glucose regulates preproinsulin messenger RNA levels in a clonal cell line of simian virus 40-transformed B cells. FEBS (Fed. Eur. Biochem. Soc.) Lett. 213:149-154.

36. de Leeuw, W. J. F., P. E. Slagboom, and J. Vijg. 1989. Quantitative comparison of mRNA levels in mammalian tissues: $28 \mathrm{~S}$ ribosomal RNA level as an accurate internal control. Nucleic Acids Res. 17:10137-10138.

37. Maniatis, T., E. F. Fritsch, and J. Sambrook. 1989. Isolation of high-molecular-weight DNA from mammalian cells. In Molecular Cloning. A Laboratory Manual. Cold Spring Harbor Laboratory, Cold Spring Harbor, NY. 9.14-9.24.

38. Southern, E. M. 1975. Detection of specific sequences among DNA fragments separated by gel electrophoresis. J. Mol. Biol. 98:503-517.

39. Walseth, T. F., H.-J. Zhang, L. K. Olson, W. A. Schroeder, and R. P. Robertson. 1989. Increase in $\mathrm{G}_{\mathrm{s}}$ and cyclic AMP generation in HIT cells. Evidence that the $45-\mathrm{kDa} \alpha$-subunit of $\mathrm{G}_{\mathrm{s}}$ has greater functional activity than the 52-kDa $\alpha$-subunit. J. Biol. Chem. 264:21106-21111.

40. Harris, B. A., J. D. Robishaw, S. M. Mumby, and A. G. Gilman. 1985. Molecular cloning of complementary DNA for the alpha subunit of the G-protein that stimulates adenylate cyclase. Science (Wash. DC). 229:1274-1277.

41. Brunzell, J. D., R. P. Robertson, R. L. Lerner, W. R. Hazzard, J. W. Ensinck, E. L. Bierman, and D. Porte, Jr. 1976. Relationships between fasting plasma glucose levels and insulin secretion during intravenous glucose tolerance tests. J. Clin. Endocrinol. Metab. 42:222-229.

42. Robertson, R. P., J. B. Halter, and D. Porte, Jr. 1976. A role for alphaadrenergic receptors in abnormal insulin secretion in diabetes mellitus. J. Clin. Invest. 57:791-795.

43. Robertson, R. P., and M. Chen. 1977. A role for prostaglandin E in defective insulin secretion and carbohydrate intolerance in diabetes mellitus. $J$. Clin. Invest. 60:747-753.

44. Giugliano, D., A. Ceriello, P. Di Pinto, F. Saccomanno, S. Gentile, and F. Cappiapuoti. 1982. Impaired insulin secretion in human diabetes mellitus: the effect of naloxone-induced opiate receptor blockade. Diabetes. 31:367-370.

45. German, M. S., L. G. Moss, and W. J. Rutter. 1990. Regulation of insulin gene expression by glucose and calcium in transfected primary islet cultures. $J$. Biol. Chem. 265:22063-22066. 